\title{
Fracture of the Coronoid and Pterygoid Processes by Firearms: Case Report
}

\author{
David Moraes de OLIVEIRA \\ Ricardo José de Holanda VASCONCELLOS \\ José Rodrigues LAUREANO FILHO \\ Rafael Vago CYPRIANO
}

Department of Oral and Maxillofacial Surgery, University of Pernambuco, Recife, PE, Brazil

\begin{abstract}
A rare case of fracture of the coronoid and the pterygoid process caused by firearms is described. A 28-year-old male was hit by a bullet in the face, resulting in restricted mouth opening, difficulty in chewing and pain when opening the mouth. Clinical examination revealed a perforating wound in the right parotid region and a similar wound on the left side of the same region. A CT scan showed comminuted fracture of the left coronoid process and bilateral comminuted fracture of the pterygoid processes. Treatment was conservative, speech therapy was conducted and it was successful. Details of the clinical signs, radiology (3D-CT scan), treatment and follow-up are presented.
\end{abstract}

Key Words: facial fracture, coronoid process, pterygoid process, gunshot.

\section{INTRODUCTION}

Mandibular fractures are relatively common injuries; fractures of the coronoid process, however, are very uncommon. Boole et al. (1) reported 5,196 mandibular fractures, of which only 30 (1\%) involved the coronoid process. Dingman and Natvig (2) stated that $2 \%$ of fractures of the mandibular condyle occur in the region of the coronoid process. Isolated coronoid fractures due to direct trauma are very uncommon because the coronoid process is anatomically sheltered by the zygomaticomalar complex and its associated muscles $(3,4)$. Most are due to direct blunt or penetrating trauma. There are several reports of iatrogenic fractures occurring during interventions, such as extractions of maxillary and mandibular third molars, cystectomies and sagittal split ramus osteotomy (5).

Natvig et al. (6) divided coronoid fractures into two types: Intramuscular: the fracture is within the attachments of the temporal muscle and its deep and superficial tendons, and there is no displacement of the fractured segment; Submuscular: the site of the fracture is below the attachments of the temporal muscle, and there is some degree of superior and medial displacement of the fragment.

Fractures of the pterygoid plate have usually been associated with Le Fort II, Le Fort III and zygomaticomaxillary compound fractures. Inability to close the mouth and subsequent open-bite deformity was attributed to spasm and possible laceration of some fibers of medial and lateral pterygoid muscles (7).

This paper presents a rare case of unilateral comminuted fracture of the coronoid process associated with a bilateral comminuted fracture of the pterygoid processes of the sphenoid bone.

\section{CASE REPORT}

A 28-year-old male patient was referred to our service 10 days after being hit by a bullet, resulting in complaints of restricted mouth opening, difficulty in chewing and pain when opening the mouth.

Correspondence: Prof. Dr. Ricardo José de Holanda Vasconcellos, Departamento de Cirurgia Bucomaxilofacial, Universidade de Pernambuco, Avenida General Newton Cavalcanti, 1650, 54753-220 Camaragibe, PE, Brasil. Tel/Fax: +55-81-3458-2867. e-mail: rholanda@fop.upe.br; davidoliveira78@uol.com.br 
Clinical extraoral examination revealed a perforating wound in the right parotid region corresponding to the orifice of entry and a similar wound on the left side of the same region corresponding to the orifice of exit (Figs. 1A and 1B). No facial palsy was observed. Intraoral examination showed normal occlusion, a restricted mouth opening of $28 \mathrm{~mm}$, deviation from the midline to the right side at the extremity of mouth opening and on protrusion, absence of lateral movement to the left side and tenderness and pain over left ascending ramus on palpation. Previous medical and surgical histories, review of systems, family and social background were noncontributory. The patient reported that there was oral bleeding at the time of trauma, which ceased spontaneously. A computer tomograph (CT) scan showed unilateral comminuted fracture of the left coronoid process and bilateral comminuted fracture of the pterygoid processes (Figs. 2A, 2B, 3A and $3 \mathrm{~B}$ ). No other major change associated with the trajectory of the bullet was observed on the images.

Treatment was conservative. Speech therapy
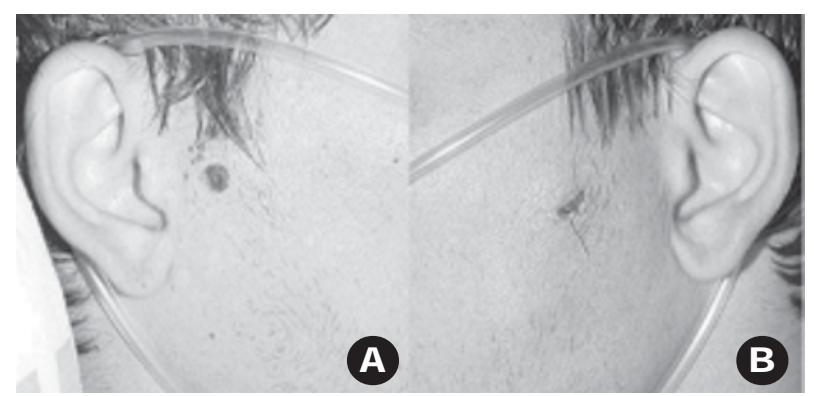

Figure 1. A: Perforating wound in the right parotid region corresponding to the orifice of entry. B: Perforating wound in the left parotid region corresponding to the orifice of exit.

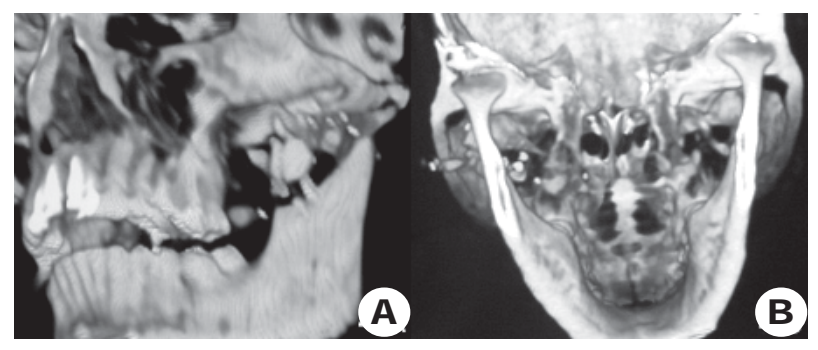

Figure 3. A: CT scan (3-D reconstruction) showing a unilateral comminuted fracture of the left coronoid process. B: CT scan (3D reconstruction) showing bilateral comminuted fracture of the pterygoid processes. was conducted for a period of four weeks as follows: three 1-h sessions per week in the presence of the speech therapist, with the patient performing the same treatment alone on the other four days. The treatment protocol was the following: 1) Relaxation of the masticatory muscles: thermotherapy with dry heat for 20 min, followed by manual massage for three minutes with the aim of increasing the blood supply and eliminating metabolic residues; 2) Mandibular exercises: mouth opening with the tongue on the palate to facilitate muscle coordination, thereby restriction deviation to the right, mouth opening with spatulas positioned in the posterior region to promote lengthening of the muscles, manual traction to prevent deviation to the right and promote lateral movement to the left, and use of a counteracting force to the opening movements, movement to the left and protrusion with the aim of promoting relaxation of the antagonist muscle and coordinating of the requested movements; 3) Functional therapy: chewing, emphasizing the contralateral side of the coronoid fracture.

On completion of the treatment with the speech

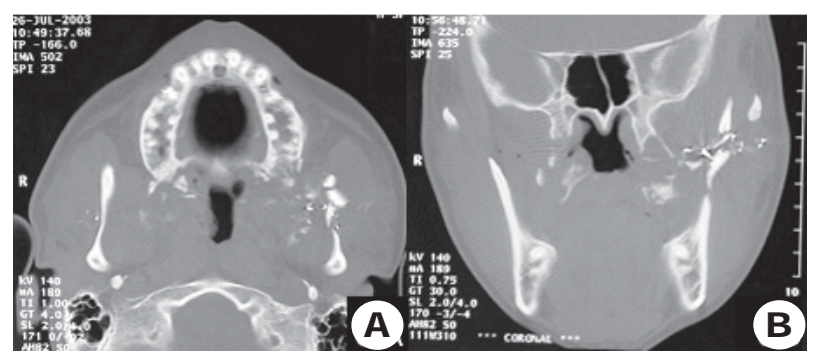

Figure 2. Axial CT scan (panel A) and coronal CT scan (panel B) showing a unilateral comminuted fracture of the left coronoid process and bilateral comminuted fracture of the pterygoid processes.

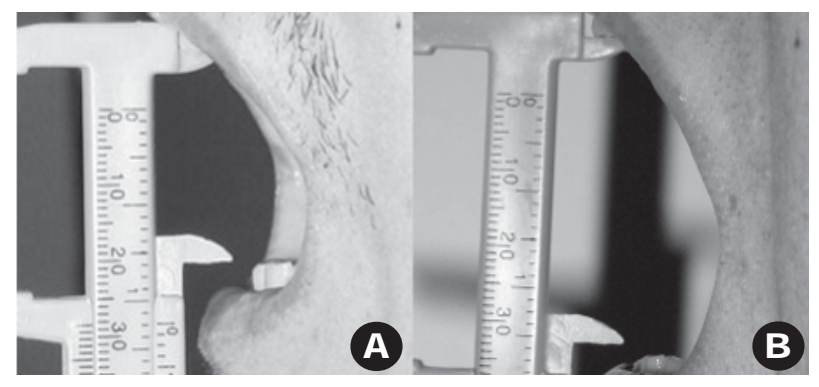

Figure 4. A: 28-mm mouth opening observed 10 days after the patient had been hit by a bullet (pretreatment photograph). B: 40-mm mouth opening observed after 9 months of treatment. 
therapist, the patient was advised to continue the exercises for additional 2 months. After 9 months of follow-up, the patient's mouth opening had increased from $28 \mathrm{~mm}$ to $40 \mathrm{~mm}$ (Figs. 4A and 4B), there was no deviation of the midline on mouth opening or protrusion, and a limited lateral movement to the left was observed.

\section{DISCUSSION}

Because of their protected position under the zygomatic arch or zygomaticomalar complex, coronoid fractures due to direct trauma are very uncommon (8). However, in this case, direct trauma caused by a gunshot resulted in an unilateral comminuted fracture, associated with the bilateral comminuted fracture of the pterygoid processes.

The radiological diagnosis of a fracture of the coronoid process is not always easy to make, and the fracture may go undetected because of inappropriate radiographs. Nevertheless, since the advent of CT scans, it is no longer difficult to correctly diagnose a coronoid fracture (9) or a fracture of the pterygoid process. In the case presented in this paper, the use of CT scans was extremely valuable in the diagnosis and, as a result, in the choice of treatment.

Treatment depends on the degree of displacement of the fractured coronoid process and the severity of the symptoms. Generally this type of fracture can be treated simply with a soft, nonchewy diet. If marked malocclusion is present and the patient complains of severe pain, intermaxillary fixation for up to 4 weeks will relieve the symptoms and encourage prompt healing. In intramuscular fractures, the muscular spasm of the temporalis is usually sufficient to hold the fragment in position until healing (3). In submuscular fractures, when the fragment is large enough and impedes mandibular function, or if there is marked lateral displacement that prevents osseous contact with the ramus, intraoral open reduction and intraosseous wiring has been advised (9). Some authors recommend removal of the coronoid process in cases with limitation of movement due to fibrosis of the temporalis muscle (8). Yaremchuk (10) used rigid internal fixation for the treatment of a displaced coronoid fracture.

In this case, the conservative treatment was preferred because the coronoid fracture was comminuted, which precluded fixation, and because the man- dibular functions were only partially impaired, with no serious involvement.

In conclusion, conservative treatment was successful, probably because there was no marked malocclusion and because the mandibular movements presented only minor changes. An early start to the treatment and close follow-up also contributed to the successful outcome.

\section{RESUMO}

Um caso raro de fratura dos processos coronóide e pterigóide por arma de fogo é descrito. Paciente do sexo masculino, 28 anos de idade, foi atingido por projétil de arma de fogo na face, resultando em limitação na abertura da boca, dificuldade para mastigar e dor ao abrir a boca. Exame clínico revelou ferimento perfurante em região parotídea direita e ferida similar do lado esquerdo na mesma região. Tomografia computadorizada (TC) mostrou fratura cominutiva do processo coronóide esquerdo e fratura cominutiva bilateral dos processo pterigóides. O tratamento foi conservador, através de fonoterapia, obtendo-se sucesso. Uma descrição detalhada das características clínicas, radiológicas (TC com reconstrução 3D), tratamento e proservação do caso é apresentada.

\section{REFERENCES}

1. Boole JR, Holtel M, Amoroso P, Yore M. 5196 mandible fractures among 4381 active duty army soldiers, 1980 to 1998. Laryngoscope 2001;111:1691-1696.

2. Dingman RO, Natvig P. Surgery of facial fractures. Philadelphia: Saunders Company, 1964.

3. Takenoshita Y, Enomoto T, Oka M. Healing of fractures of the coronoid process: report of cases. J Oral Maxillofac Surg 1993;51:200-204.

4. Vanhove F, Dom M, Wackens G. Fracture of the coronoid process: report of a case. Acta Stomatol Belg 1997;94:8185.

5. Farish SE. Iatrogenic fracture of the coronoid process: report of a case. J Oral Surg 1972;30:848-850.

6. Natvig P, Sicher H, Fodor PB. The rare isolated fracture of the coronoid process of the mandible. Plast Reconstr Surg 1970;46:168-172.

7. Archer CR, Sundaram M. Uncommon sphenoidal fractures and their sequelae. Radiology 1977;122:157-161.

8. Jonhson RL. Unusual (coronoid) fracture of the mandible: report of a case. J Oral Surg 1958;16:73.

9. Rapidis DA, Papavassiliou D, Papadimitriou J, Koundouris J, Zachariadis N. Fractures of the coronoid process of the mandible. An analysis of 52 cases. Int $\mathrm{J}$ Oral Surg 1985;14:126-130.

10. Yaremchuk MJ. Rigid internal fixation of a displaced mandibular coronoid fracture. J Craniofac Surg 1992;3:226-229.

Accepted October 30, 2006 